\title{
An assessment of differences in lower stratospheric temperature records from (A)MSU, radiosondes, and GPS radio occultation
}

\author{
F. Ladstädter ${ }^{1}$, A. K. Steiner ${ }^{1}$, U. Foelsche ${ }^{1}$, L. Haimberger ${ }^{2}$, C. Tavolato ${ }^{2}$, and G. Kirchengast ${ }^{1}$ \\ ${ }^{1}$ Wegener Center for Climate and Global Change (WEGC) and Institute for Geophysics, Astrophysics, and Meteorology/Inst. \\ of Physics (IGAM/IP), University of Graz, Graz, Austria \\ ${ }^{2}$ Department of Meteorology and Geophysics, University of Vienna, Vienna, Austria
}

Received: 1 March 2011 - Published in Atmos. Meas. Tech. Discuss.: 7 April 2011

Revised: 15 August 2011 - Accepted: 18 September 2011 - Published: 21 September 2011

\begin{abstract}
Uncertainties for upper-air trend patterns are still substantial. Observations from the radio occultation (RO) technique offer new opportunities to assess the existing observational records there. Long-term time series are available from radiosondes and from the (Advanced) Microwave Sounding Unit (A)MSU. None of them were originally intended to deliver data for climate applications. Demanding intercalibration and homogenization procedures are required to account for changes in instrumentation and observation techniques. In this comparative study three (A)MSU anomaly time series and two homogenized radiosonde records are compared to RO data from the CHAMP, SAC-C, GRACE-A and F3C missions for September 2001 to December 2010. Differences of monthly anomalies are examined to assess the differences in the datasets due to structural uncertainties. The difference of anomalies of the (A)MSU datasets relative to RO shows a statistically significant trend within about $(-0.2 \pm 0.1) \mathrm{K} / 10 \mathrm{yr}(95 \%$ confidence interval) at all latitudes. This signals a systematic deviation of the two datasets over time. The radiosonde network has known deficiencies in its global coverage, with sparse representation of most of the Southern Hemisphere, the tropics and the oceans. In this study the error that results from sparse sampling is estimated and accounted for by subtracting it from radiosonde and RO datasets. Surprisingly the sampling error correction is also important in the Northern Hemisphere (NH), where the radiosonde network is dense over the continents but does not capture large atmospheric variations in $\mathrm{NH}$ winter. Considering the sampling error, the consistency of radiosonde and $\mathrm{RO}$ anomalies is improving substantially; the trend in the anomaly differences is generally very small. Regarding (A)MSU, its poor vertical
\end{abstract}

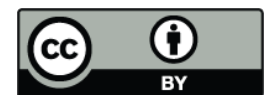

Correspondence to: F. Ladstädter (florian.ladstaedter@uni-graz.at) resolution poses another problem by missing important features of the vertical atmospheric structure. This points to the advantage of homogeneously distributed measurements with high vertical resolution.

\section{Introduction}

The upper troposphere-lower stratosphere (UTLS) region is known to react sensitively to climate change (Baldwin et al., 2007). High-quality observations are crucial to assess the anthropogenic influence on the climate system in the UTLS. It is well known that the temperature trend patterns in the troposphere and stratosphere can provide valuable information on the mechanisms of climate change (Karl et al., 2006; Solomon et al., 2007; Thompson and Solomon, 2005). Until now observational data exist primarily from radiosondes (since 1958) and from the (Advanced) Microwave Sounding Unit (A)MSU instrument flying on US National Oceanic and Atmospheric Administration (NOAA) polar orbiting satellites (since 1979). However, none of these existing long-term measurement systems for the upper-air were originally intended to be used for climate monitoring purposes. While surface temperature trends are in accordance amongst different groups (Solomon et al., 2007), the uncertainties regarding trend values for the upper-air are still substantial (Randel et al., 2009; Randall and Herman, 2008; Titchner et al., 2009). The main reasons for these uncertainties derive from demanding intercalibration and homogenization procedures. These structural uncertainties have been results of changing instrumentation and observation practice over the decades (Karl et al., 2006; Thorne et al., 2005). This is true for both main sources of upper-air temperature data. The radiosonde time series has specifically experienced numerous changes in their stations, types of sensors, and changes in

Published by Copernicus Publications on behalf of the European Geosciences Union. 
data processing systems. Using advanced homogenization techniques, these artificial data discontinuities are reduced (Haimberger, 2007; Haimberger et al., 2008). The sparse spatial sampling is causing further uncertainties in the global radiosonde stations' network (Free and Seidel, 2005). Unlike radiosondes, (A)MSU data provide very good global coverage. The instrumentation biases introduced in the chain of NOAA satellites (most recent being NOAA-19) still need to be accounted for. Further errors affecting (A)MSU data include shifts in the diurnal sampling, orbit variations and calibration changes (Karl et al., 2006). Many of these issues are addressed by calibrated datasets produced by different groups (Christy et al., 2007; Mears and Wentz, 2009a; Zou et al., 2009).

There have been significant efforts in the past to create reliable climate records despite these obstacles (Mears and Wentz, 2009a; Christy et al., 2003; Haimberger et al., 2008; Zou and Wang, 2010). It has been argued that the uncertainties in upper-air temperature trends are inevitable due to structural uncertainties involved in the methodology (Thorne et al., 2005). Increasing the number of independent datasets decreases the structural uncertainty (Seidel et al., 2004). The need for new upper-air measurement systems has already been stated by the implementation plan for the Global Observing System for Climate (GCOS, 2010). One already existing relatively new system is GPS radio occultation (RO) that can be considered as of potential benchmark quality (Steiner et al., 2009b). RO uses Global Positioning System (GPS) radio signals in limb sounding geometry to deliver observations in the UTLS region with high accuracy, global coverage, and high vertical resolution (Melbourne et al., 1994; Kursinski et al., 1997; Steiner et al., 2001; Hajj et al., 2002). Additionally it is self-calibrating, thus avoiding error-prone intercalibration procedures. These properties make the technique well qualified to be used for climate applications, as has been shown in a considerable number of publications (e.g., Scherllin-Pirscher et al., 2011b; Steiner et al., 2009b; Foelsche et al., 2009; Ho et al., 2009b; Leroy et al., 2006). Therefore RO can be considered a good choice to assess the adequacy of the observational data mentioned above for climate applications. This has been done in several previous studies for (A)MSU (Schrøder et al., 2003; Ho et al., 2007; Steiner et al., 2007, 2009a). Regarding radiosondes, Kuo et al. (2005), He et al. (2009), and Sun et al. (2010) concluded that RO soundings are of sufficient quality to differentiate between different types of radiosondes. Steiner et al. (2007, 2009a), and Ho et al. (2007) found significant differences between RO and (A)MSU records. Ho et al. (2009a) suggested to use RO data for calibration of (A)MSU temperatures.

This study advances previous work (Steiner et al., 2007), using the most recent datasets for RO, (A)MSU and radiosondes, and substantially longer records. It furthermore improves on previous work by analysing error characteristics of RO and radiosondes resulting from sparse spatial and

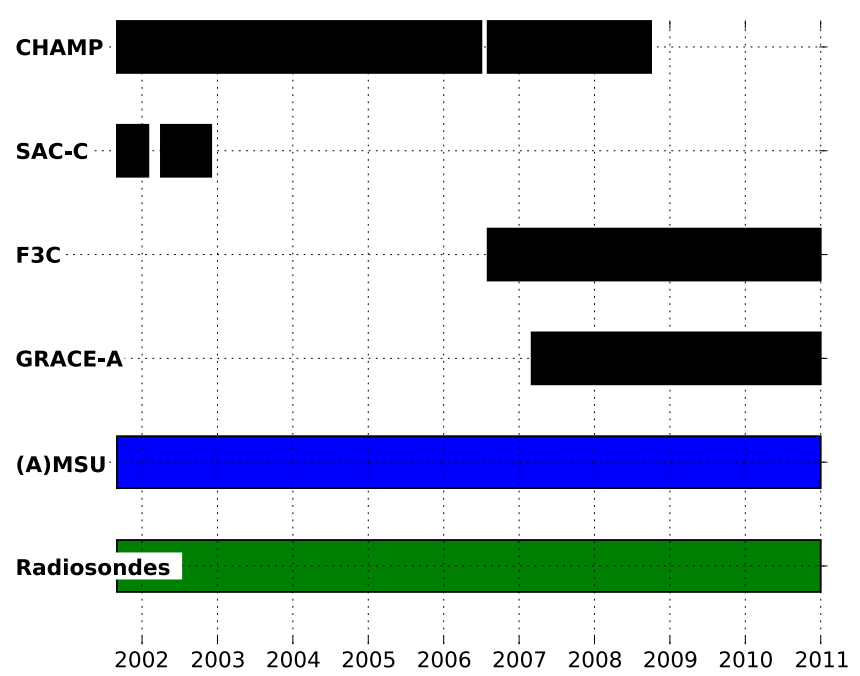

Fig. 1. Time frames of datasets used (black, GPS RO datasets).

temporal sampling. The data used in this study are briefly introduced in Sect. 2, the method of comparison and assessing sampling error characteristics is described in Sect. 3, the results are discussed in Sect. 4, followed by a summary of the results and conclusions of this comparative study.

\section{Data}

The comparison time range is limited by the availability of continuous RO data. The CHAMP satellite (Wickert et al., 2001) delivered data from September 2001 to September 2008. Data from the FORMOSAT-3/COSMIC (F3C) mission (Anthes et al., 2008) are used starting from August 2006 until December 2010. Available data from SAC-C (2001, 2002) (Hajj et al., 2004) and GRACE-A (2007 to 2010) (Beyerle et al., 2005) are also used. The study time frame is therefore September 2001 to December 2010 (Fig. 1).

\subsection{GPS Radio Occultation}

We use CHAMP, SAC-C, GRACE-A, and F3C profiles from September 2001 to December 2010 as processed by the Wegener Center for Climate and Global Change (WEGC). We applied the current processing scheme OPSv5.4 (Occultation Processing System, version 5.4) to excess phase data and precise orbit information provided by the University Corporation for Atmospheric Research (UCAR) (Pirscher, 2010). The data of the various instruments can be combined to a consistent single climate record as long as the processing chain is the same for all sources (Pirscher, 2010; Foelsche et al., 2011). Only high-quality profiles are provided and can be downloaded from the global climate monitoring website ${ }^{1}$.

\footnotetext{
${ }^{1}$ www.wegcenter.at/globclim
} 
July 2003: No. of Radio Occultation Profiles
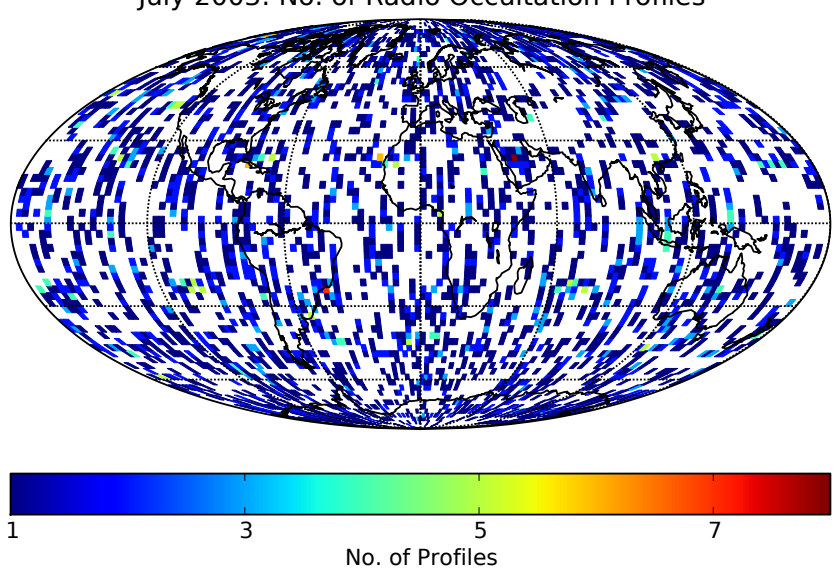

July 2007: No. of Radio Occultation Profiles
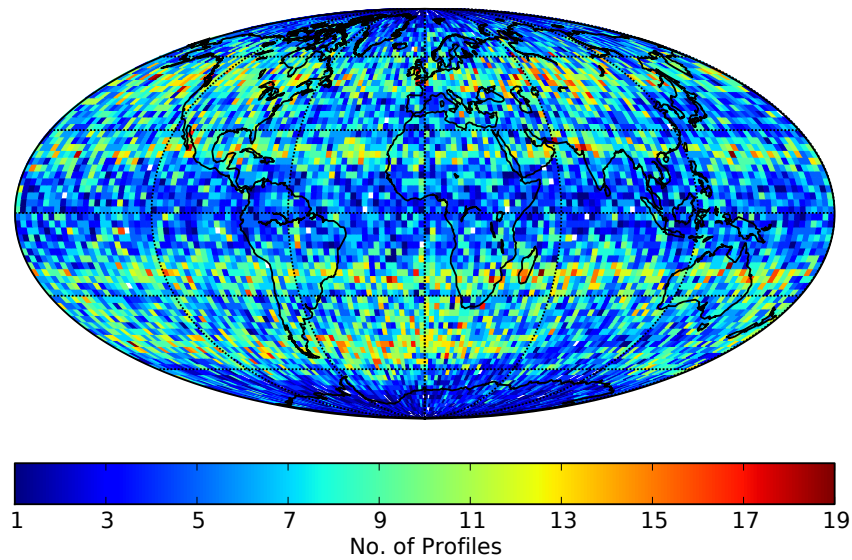

Fig. 2. Global monthly coverage of RO profiles for July 2003 (top) single-satellite (CHAMP) and for July 2007 (bottom) multi-satellite data (CHAMP, COSMIC, GRACE-A). Number of profiles in $2.5^{\circ} \times$ $2.5^{\circ}$ bins are shown.

We use dry-temperature profiles in an altitude range of $4 \mathrm{~km}$ to $35 \mathrm{~km}$ at a vertical resolution of $0.1 \mathrm{~km}$. The RO specific dry-temperature is essentially the same as actual temperature at altitudes above $10 \mathrm{~km}$ where moisture is negligible (Scherllin-Pirscher et al., 2011a). Therefore it can be directly used to study the (A)MSU lower stratosphere channel of interest here (Steiner et al., 2007, 2009a). The number of profiles ranges from about 120 to 160 per day (single-satellite) up to about 2000 per day (multi-satellite); see the representative example months in Fig. 2. In both cases the observations are distributed approximately uniformly in space and time within each month.

\section{2 (Advanced) Microwave Sounding Unit}

The (Advanced) Microwave Sounding Unit ([A]MSU) instruments provide satellite-based nadir measurements of layer-average brightness temperatures. The instruments fly on board of the NOAA series of polar orbiting satellites.
We use calibrated post-processed data from three different groups, all of them provided at $2.5^{\circ} \times 2.5^{\circ}$ horizontal resolution. The AMSU instruments are in orbit since 1998, while the last NOAA satellite with an MSU instrument aboard was decommissioned in 2007 (NOAA-14), with decreasing data continuity after 2004 . Therefore, during this overlap time contained in the study time frame, the (A)MSU datasets include data from both instrument types.

The bulk temperature of the lower stratosphere region (TLS) corresponds to MSU channel 4 and AMSU channel 9, respectively. These two channels match each other fairly well in order to ensure continuation of the temperature time series. Remaining differences between the MSU and the AMSU instrument are accounted for in the merging procedures of the processing groups so that the time series matches the MSU data (Mears and Wentz, 2009b).

The layer between $150 \mathrm{hPa}$ and $30 \mathrm{hPa}(\approx 13 \mathrm{~km}$ to $25 \mathrm{~km})$ contributes most to the TLS layer mean temperature, peaking at around $90 \mathrm{hPa}(\approx 18 \mathrm{~km})$ (Christy et al., 2003). The poor vertical resolution results in considerable influence of the troposphere to the TLS in the tropics.

TLS brightness temperatures were retrieved from the University of Alabama at Huntsville (UAH) (Christy et al., 2003) in version UAHv5.4 ${ }^{2}$ from Remote Sensing Systems (RSS) (Mears and Wentz, 2009a) in version RSSv3.3; ${ }^{3}$ and from the National Environmental Satellite, Data and Information Service (NESDIS) Center for Satellite Applications and Research (STAR) (Zou et al., 2009) in version STARv2.0. ${ }^{4}$

\subsection{Radiosondes}

For this comparison, we use the latest homogenized radiosonde datasets: The Radiosonde Observation using Reanalysis (RAOBCORE) dataset (Haimberger, 2007) and the Radiosonde Innovation Composite Homogenization (RICH) dataset (Haimberger et al., 2008), both in version 1.5. Compared to the already published version 1.4 , the new version uses raw radiosonde data and background forecast data from ERA-Interim (Dee et al., 2011) instead of operational ECMWF analyses. More than 1000 stations are used. 00:00 UTC and 12:00 UTC launches are kept separately. Figure 3 shows the global coverage of these archives and indicates the launch times. The homogenization procedure works on daily data, which enables very effective breakpoint detection.

RAOBCORE uses time series of the ERA-Interim background forecasts as reference for homogenization. RAOBCORE is therefore, strictly speaking, not independent of satellite data, because ERA-Interim contains (A)MSU information. RICH uses the breakpoints detected by RAOBCORE, but relies only on up to 30 neighboring stations for

\footnotetext{
${ }^{2}$ http://vortex.nsstc.uah.edu/data/msu/

${ }^{3}$ http://www.remss.com/msu/msu_browse.html

${ }^{4} \mathrm{ftp}$ ://ftp.orbit.nesdis.noaa.gov/pub/smcd/emb/mscat/data/v2.0/
} 

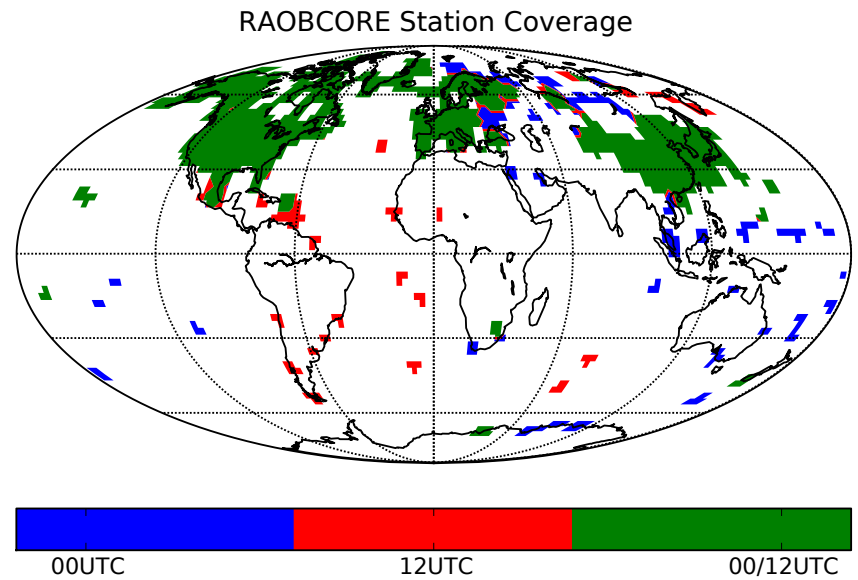

Fig. 3. Global coverage of radiosonde launches used in the RAOBCORE and RICH datasets. The color code shows whether there are launches at 00UTC (blue), 12:00 UTC (red), or at both times (green), in the corresponding $2.5^{\circ} \times 2.5^{\circ}$ bin.

the actual homogenization. It is therefore a completely independent dataset (Haimberger et al., 2008).

The radiosonde data are available on 12 pressure levels from $850 \mathrm{hPa}$ to $30 \mathrm{hPa} .{ }^{5}$ For both homogenized radiosonde time series, the University of Vienna used the Radiative Transfer for TOVS (RTTOV) model (Saunders, 2008) to construct MSU-equivalent brightness temperature (TLS) anomalies. The TLS values were then binned into a $2.5^{\circ} \times 2.5^{\circ}$ horizontal grid. ${ }^{6}$

\subsection{ECMWF}

As reference dataset in the estimation of sampling error characteristics of RO and radiosondes (see method description in Sect. 3), we use the ECMWF operational analysis fields. For each RO profile, OPSv5.4 extracts a collocated profile from the global ECMWF field at T42 resolution, comparable to the horizontal resolution of RO (Scherllin-Pirscher et al., 2011b). The analysis fields are available for four time layers, 00:00 UTC, 06:00 UTC, 12:00 UTC, and 18:00 UTC. The 00:00 UTC and 12:00 UTC time layers correspond to the radiosonde launch times and are used in $2.5^{\circ} \times 2.5^{\circ}$ horizontal resolution on 25 pressure levels (from $1 \mathrm{hPa}$ to $1000 \mathrm{hPa}$ ) as collocated fields to radiosonde data at station locations. The vertical resolution was increased in 2007, but additional levels after 2007 were introduced below $500 \mathrm{hPa}$ only, which has no effect on the TLS. The averaged field over all time layers is used as reference for the radiosondes and RO, as described in the next section.

\footnotetext{
${ }^{5} 850 \mathrm{hPa}, 700 \mathrm{hPa}, 500 \mathrm{hPa}, 400 \mathrm{hPa}, 300 \mathrm{hPa}, 250 \mathrm{hPa}, 200 \mathrm{hPa}$, $150 \mathrm{hPa}, 100 \mathrm{hPa}, 70 \mathrm{hPa}, 50 \mathrm{hPa}, 30 \mathrm{hPa}$

${ }^{6} \mathrm{http}: / /$ www.univie.ac.at/theoret-met/research/raobcore/
}

\section{Method}

The different comparisons in this study are based on TLS layer-average brightness temperatures ("MSU-equivalent"). We compare monthly and zonal means for regularly-spaced $20^{\circ}$ bands and for four regions, tropics $\left(20^{\circ} \mathrm{S}\right.$ to $\left.20^{\circ} \mathrm{N}\right)$, extra-tropics $\left(70^{\circ} \mathrm{S}\right.$ to $30^{\circ} \mathrm{S}$ and $30^{\circ} \mathrm{N}$ to $\left.70^{\circ} \mathrm{N}\right)$, and quasiglobal $\left(70^{\circ} \mathrm{S}\right.$ to $\left.70^{\circ} \mathrm{N}\right)$.

\subsection{Setup of comparable data}

Consistent with the computational procedure applied for radiosonde profiles (see Sect. 2.3), we use RTTOV to compute layer-average TLS from RO and collocated ECMWF temperature profiles. RTTOV uses internally 43 vertical levels from $0.1 \mathrm{hPa}$ to $1013 \mathrm{hPa}$. The input profiles are interpolated to these levels. To match the horizontal and temporal resolutions of the other datasets, we then bin the resulting TLS field into a $2.5^{\circ} \times 2.5^{\circ}$ grid (monthly means). Averaging involves weighting by the cosine of the latitude, which accounts for area changes between meridians of different latitudes (Foelsche et al., 2008a). This is only a minor effect at this resolution though. We do not distinguish between the various RO missions, all available RO profiles are incorporated into the respective monthly mean. As noted above, this procedure is justified given that the processing chain is the same for all sources (up to negligible differences in raw processing) and that the inter-satellite consistency is thus very high (Foelsche et al., 2011).

The ECMWF analysis field at $2.5^{\circ} \times 2.5^{\circ}$ resolution is also processed by RTTOV separately for all four available time layers. As a result, all datasets involved in this comparison are now available at the same monthly-means, $2.5^{\circ} \times 2.5^{\circ}$ resolution and in MSU-equivalent TLS. In Fig. 4 we show representative TLS fields for RO and differences of RO to STAR for two months (Northern Hemisphere $(\mathrm{NH})$ winter and summer). TLS temperatures of RO and STAR show larger deviations at higher latitudes, but are generally in very good agreement, especially on a zonal mean scale as used below.

In the next step, we create latitudinal bands by simply averaging over all bins at each respective latitude. Then we aggregate those to larger bands. Here we apply weighting with the surface area of the bands involved. This approach accounts for the decreasing area of latitude bands of equal width (Foelsche et al., 2011).

\subsection{Sampling error estimation}

All observational datasets inherently differ from reality because of their finite sampling of the atmosphere. Depending on the sampling density and the variability of the atmosphere, it often is essential to account for this difference. A decent approach to estimate the magnitude of error made by discrete sampling is to compare atmospheric fields to a 

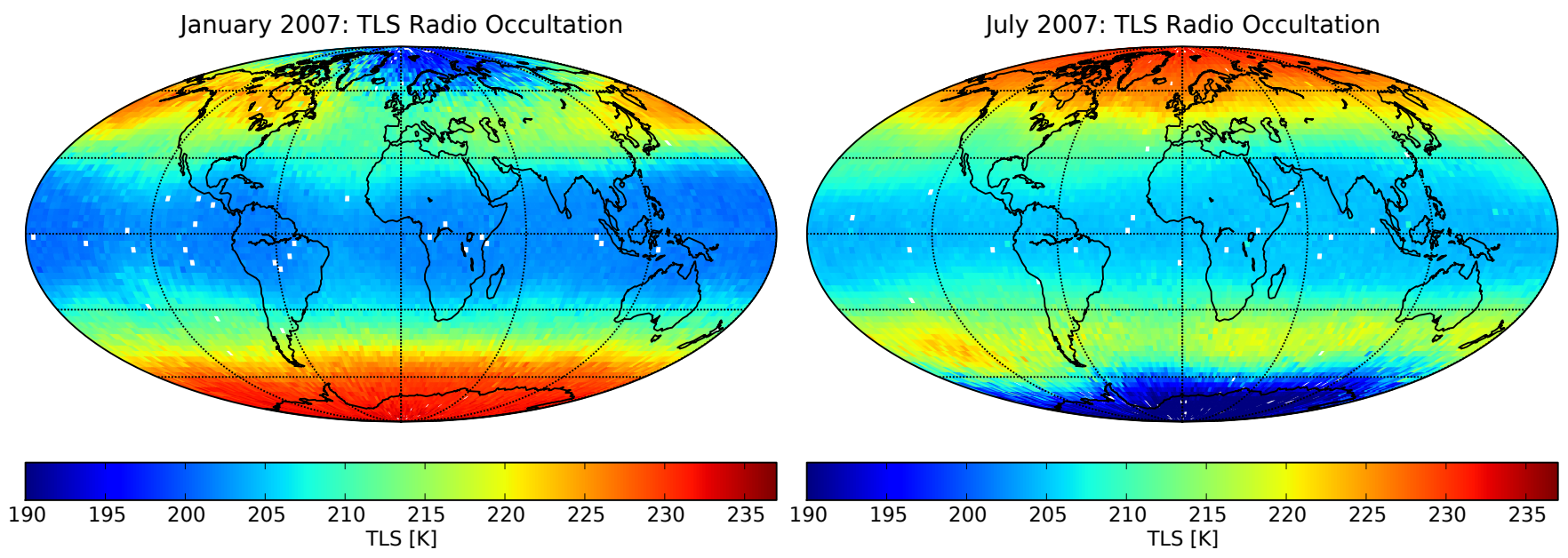

January 2007: TLS Difference RO-STAR
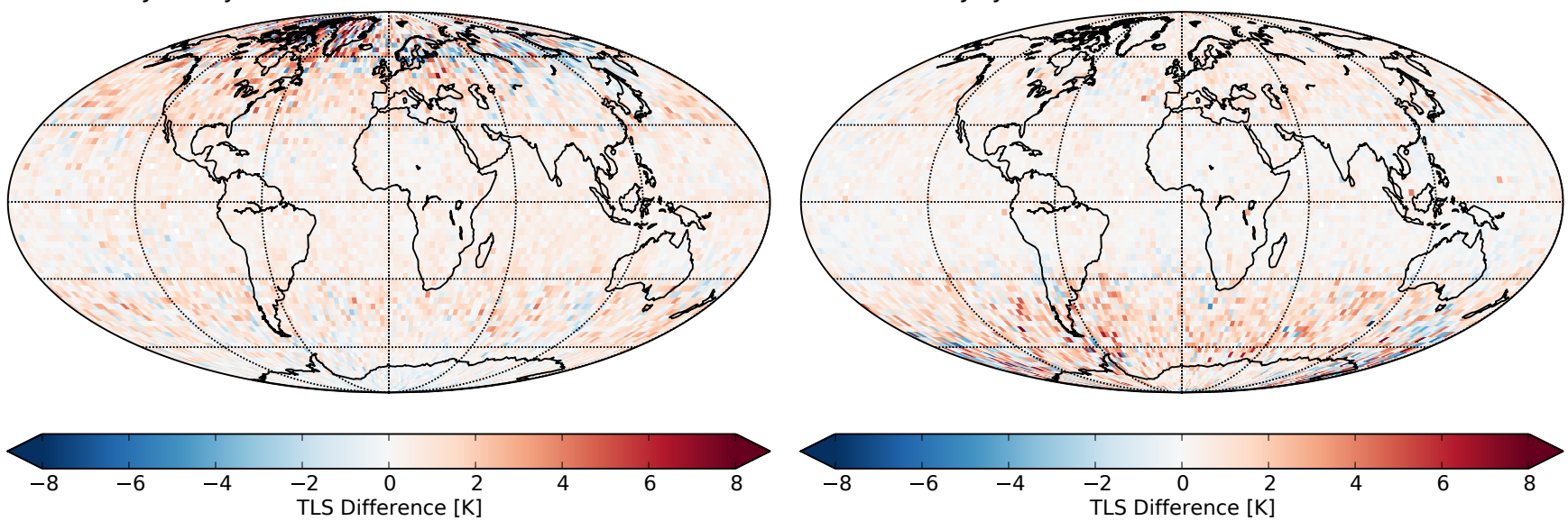

Fig. 4. Brightness temperatures (TLS) for two monthly means at $2.5^{\circ} \times 2.5^{\circ}$ resolution. (left) January 2007, (right) July 2007 , (top) Radio occultation synthetic TLS, (bottom) Difference of RO synthetic TLS to AMSU TLS (STAR).

"true" reference field (Foelsche et al., 2008a). In this study, the sampling error estimation for $\mathrm{RO}$ and radiosondes is performed consistently. We do not consider sampling error for (A)MSU because we can assume that the error reaches virtually zero due to high horizontal resolution of the dataset. Potential temporal (A)MSU sampling errors caused by diurnal cycle drifts are already accounted for in the homogenized (A)MSU datasets (Christy et al., 1998; Mears and Wentz, 2009b).

We use ECMWF analysis fields for all four time layers assuming that they are valid approximations of the "true" global field. The methodology for estimating the sampling error of RO is described in detail elsewhere (Pirscher, 2010; Foelsche et al., 2008a). In short, the collocated ECMWF profiles are averaged to latitudinal bands and monthly means as described above. They represent the atmospheric state at the times and locations of RO measurements as seen by the reference field. We then subtract the full reference field, representing the "true" atmospheric state. We define this dif- ference as sampling error of RO for the respective month and latitudinal band. We finally subtract the estimated deseasonalized sampling error from RO anomalies. This substantially improves the quality of RO climatological fields as has been shown in several studies (Foelsche et al., 2011; Scherllin-Pirscher et al., 2011a). The actual data is thus not used for estimating the sampling error.

In contrast to satellite measurements, the global coverage of radiosondes is not uniform. Most notable, the Southern Hemisphere $(\mathrm{SH})$, the tropics, and the oceans are sparsely represented. In other regions, especially over the NH continents, the coverage is good. Free and Seidel (2005) stated that the concentration of stations in those regions does not necessarily improve the dataset because it oversamples those continental areas while under-representing the oceans. At most of the stations in the $\mathrm{SH}$, radiosonde launches occur only once a day, see Fig. 3. Using an equivalent approach as for RO we estimate the sampling error for radiosondes. We take the ECMWF analysis fields for 00:00 UTC and 

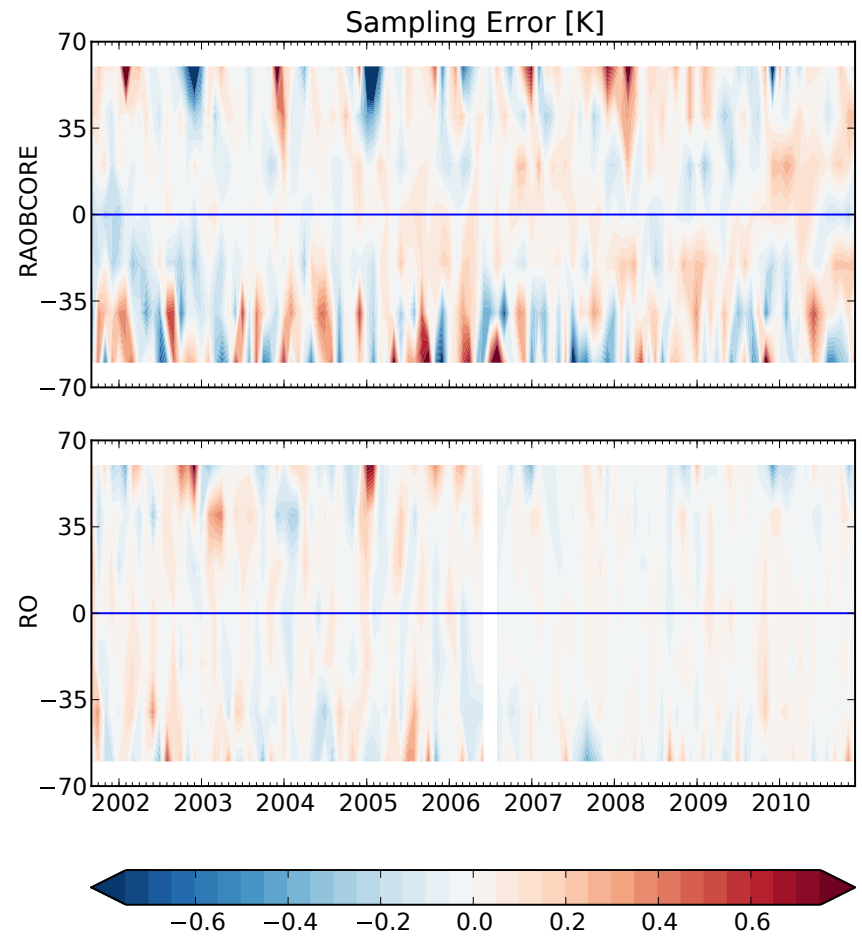

Fig. 5. Sampling error of (top) radiosondes and (bottom) RO. Shown are latitudinal bands at $20^{\circ}$ resolution.

12:00 UTC separately, and sub-sample the $2.5^{\circ} \times 2.5^{\circ}$ fields to bins where we have radiosonde data for the respective time. This results in a temporally and spatially collocated reference field, analogous to the method above described for RO. After averaging to latitudinal bands we subtract the full reference field containing all four time layers to get the sampling error for radiosondes. Finally we subtract the sampling error from the radiosonde data as we did for RO.

\subsection{Computation of TLS anomalies and anomaly differences}

For RO and (A)MSU data, we calculate monthly TLS anomalies relative to the period 2002 to 2010 to deseasonalize the data. The radiosonde time series are already provided in anomaly space for the same reference time period. After subtracting the respective de-seasonalized sampling error from $\mathrm{RO}$ and radiosonde anomalies (as described above), we compute differences of these anomaly time series. Thereby the climatological variability common to both datasets is removed. Then remaining are the differences due to structural uncertainties. We then compute the linear trends in the anomalies and anomaly differences and their statistical significance to assess deviations between the datasets. In particular, a statistically significant trend of the anomaly differences indicates that both datasets involved behave differently in their time evolution.
Table 1. Trends of anomalies for the period of Sep. 2001 to Dec. 2010. The \pm value defines the $95 \%$ confidence intervals for the trends. Trend values which are significantly different from 0 at the $90 \%$ and $95 \%$ level are marked by a single and double asterisk, respectively.

\begin{tabular}{|c|c|c|}
\hline Dataset & Trend (K/10 years) & $\operatorname{StdDev}_{\text {Residuals }}(\mathrm{K})$ \\
\hline \multicolumn{3}{|c|}{$70^{\circ} \mathrm{S}$ to $70^{\circ} \mathrm{N}$} \\
\hline RO & $+0.057 \pm 0.133$ & 0.19 \\
\hline RAOBCORE & $+0.137 \pm 0.128 * *$ & 0.19 \\
\hline $\mathrm{RICH}$ & $+0.045 \pm 0.130$ & 0.19 \\
\hline UAH & $-0.140 \pm 0.130 * *$ & 0.19 \\
\hline RSS & $-0.149 \pm 0.132 * *$ & 0.19 \\
\hline STAR & $-0.162 \pm 0.126^{* *}$ & 0.18 \\
\hline \multicolumn{3}{|c|}{$20^{\circ} \mathrm{S}$ to $20^{\circ} \mathrm{N}$} \\
\hline RO & $+0.351 \pm 0.404 *$ & 0.59 \\
\hline RAOBCORE & $+0.342 \pm 0.443$ & 0.64 \\
\hline $\mathrm{RICH}$ & $+0.225 \pm 0.439$ & 0.64 \\
\hline UAH & $+0.137 \pm 0.374$ & 0.54 \\
\hline RSS & $+0.138 \pm 0.388$ & 0.56 \\
\hline STAR & $+0.111 \pm 0.364$ & 0.53 \\
\hline \multicolumn{3}{|c|}{$30^{\circ} \mathrm{N}$ to $70^{\circ} \mathrm{N}$} \\
\hline RO & $+0.222 \pm 0.344$ & 0.50 \\
\hline RAOBCORE & $+0.237 \pm 0.333$ & 0.48 \\
\hline RICH & $+0.098 \pm 0.333$ & 0.48 \\
\hline UAH & $-0.033 \pm 0.330$ & 0.48 \\
\hline RSS & $-0.028 \pm 0.336$ & 0.49 \\
\hline STAR & $-0.062 \pm 0.321$ & 0.47 \\
\hline \multicolumn{3}{|c|}{$70^{\circ} \mathrm{S}$ to $30^{\circ} \mathrm{S}$} \\
\hline $\mathrm{RO}$ & $-0.743 \pm 0.451 * *$ & 0.66 \\
\hline RAOBCORE & $-0.752 \pm 0.474 * *$ & 0.69 \\
\hline RICH & $-0.712 \pm 0.470 * *$ & 0.68 \\
\hline UAH & $-0.864 \pm 0.449 * *$ & 0.65 \\
\hline RSS & $-0.905 \pm 0.456 * *$ & 0.66 \\
\hline STAR & $-0.870 \pm 0.444 * *$ & 0.65 \\
\hline
\end{tabular}

\section{Results}

\subsection{Sampling error}

Only by considering the sampling error for both RO and radiosonde records, a consistent comparison is possible. In Fig. 5 the resulting sampling error for radiosondes and RO is shown for $20^{\circ}$ zonal bands from $70^{\circ} \mathrm{S}$ to $70^{\circ} \mathrm{N}$.

For RO, the sampling error is generally very small $(<$ $0.2 \mathrm{~K}$ ), except at high latitudes, where it becomes increasingly difficult to capture atmospheric variability (ScherllinPirscher et al., 2011a). The additional F3C multi-satellite data as of 2006 provide only moderate reduction of the RO sampling error. For the monthly and zonal means considered in this study, the essential atmospheric variability is already 
Table 2. Trends of anomaly differences for the period of Sep. 2001 to Dec. 2010. The \pm value defines the $95 \%$ confidence intervals for the trends. Trend values which are significantly different from 0 at the $90 \%$ and $95 \%$ level are marked by a single and double asterisk, respectively.

\begin{tabular}{|c|c|c|}
\hline Datasets & Trend (K/10 years) & $\operatorname{StdDev}_{\text {Residuals }}(\mathrm{K})$ \\
\hline \multicolumn{3}{|c|}{$70^{\circ} \mathrm{S}$ to $70^{\circ} \mathrm{N}$} \\
\hline RAOBCORE-RO & $+0.080 \pm 0.061 * *$ & 0.09 \\
\hline RICH-RO & $-0.013 \pm 0.065$ & 0.10 \\
\hline UAH-RO & $-0.198 \pm 0.042 * *$ & 0.06 \\
\hline RSS-RO & $-0.206 \pm 0.043^{* *}$ & 0.06 \\
\hline STAR-RO & $-0.220 \pm 0.045^{* *}$ & 0.07 \\
\hline \multicolumn{3}{|c|}{$20^{\circ} \mathrm{S}$ to $20^{\circ} \mathrm{N}$} \\
\hline RAOBCORE-RO & $-0.012 \pm 0.083$ & 0.12 \\
\hline RICH-RO & $-0.129 \pm 0.089 * *$ & 0.13 \\
\hline UAH-RO & $-0.216 \pm 0.061 * *$ & 0.09 \\
\hline RSS-RO & $-0.215 \pm 0.058 * *$ & 0.08 \\
\hline STAR-RO & $-0.242 \pm 0.071 * *$ & 0.10 \\
\hline \multicolumn{3}{|c|}{$30^{\circ} \mathrm{N}$ to $70^{\circ} \mathrm{N}$} \\
\hline RAOBCORE-RO & $+0.014 \pm 0.061$ & 0.09 \\
\hline RICH-RO & $-0.125 \pm 0.063^{* *}$ & 0.09 \\
\hline UAH-RO & $-0.256 \pm 0.051 * *$ & 0.07 \\
\hline RSS-RO & $-0.252 \pm 0.045^{* *}$ & 0.06 \\
\hline STAR-RO & $-0.286 \pm 0.054 * *$ & 0.08 \\
\hline \multicolumn{3}{|c|}{$70^{\circ} \mathrm{S}$ to $30^{\circ} \mathrm{S}$} \\
\hline RAOBCORE-RO & $-0.006 \pm 0.139$ & 0.20 \\
\hline RICH-RO & $+0.034 \pm 0.139$ & 0.20 \\
\hline UAH-RO & $-0.118 \pm 0.055^{* *}$ & 0.08 \\
\hline RSS-RO & $-0.159 \pm 0.052 * *$ & 0.08 \\
\hline STAR-RO & $-0.124 \pm 0.056^{* *}$ & 0.08 \\
\hline
\end{tabular}

captured by a single satellite (Pirscher et al., 2007; Foelsche et al., 2008b, 2009).

For radiosondes (cf. Fig. 5, top), the sampling error is rather small $(<0.3 \mathrm{~K})$ between about $50^{\circ} \mathrm{S}$ to $50^{\circ} \mathrm{N}$. For higher latitudes the sampling error becomes large. We attribute this to greater variability of the atmosphere at higher latitudes and to the small number of stations in the SH. The sampling density in the tropics is also small but seems to be sufficient to capture the main features of atmospheric variability there. The patterns in southern and northern high latitudes differ substantially: While in the SH temporal evolution of the sampling error seems to be a rather random effect related to sparse sampling, the pattern in the NH shows a clear relation to the $\mathrm{NH}$ winter. Every $\mathrm{NH}$ winter the sampling error reaches a maximum. Comparing with Fig. 4 (top left), showing the TLS pattern in January, implies that the radiosonde network misses the large atmospheric variability in winter. This results in a larger sampling error.
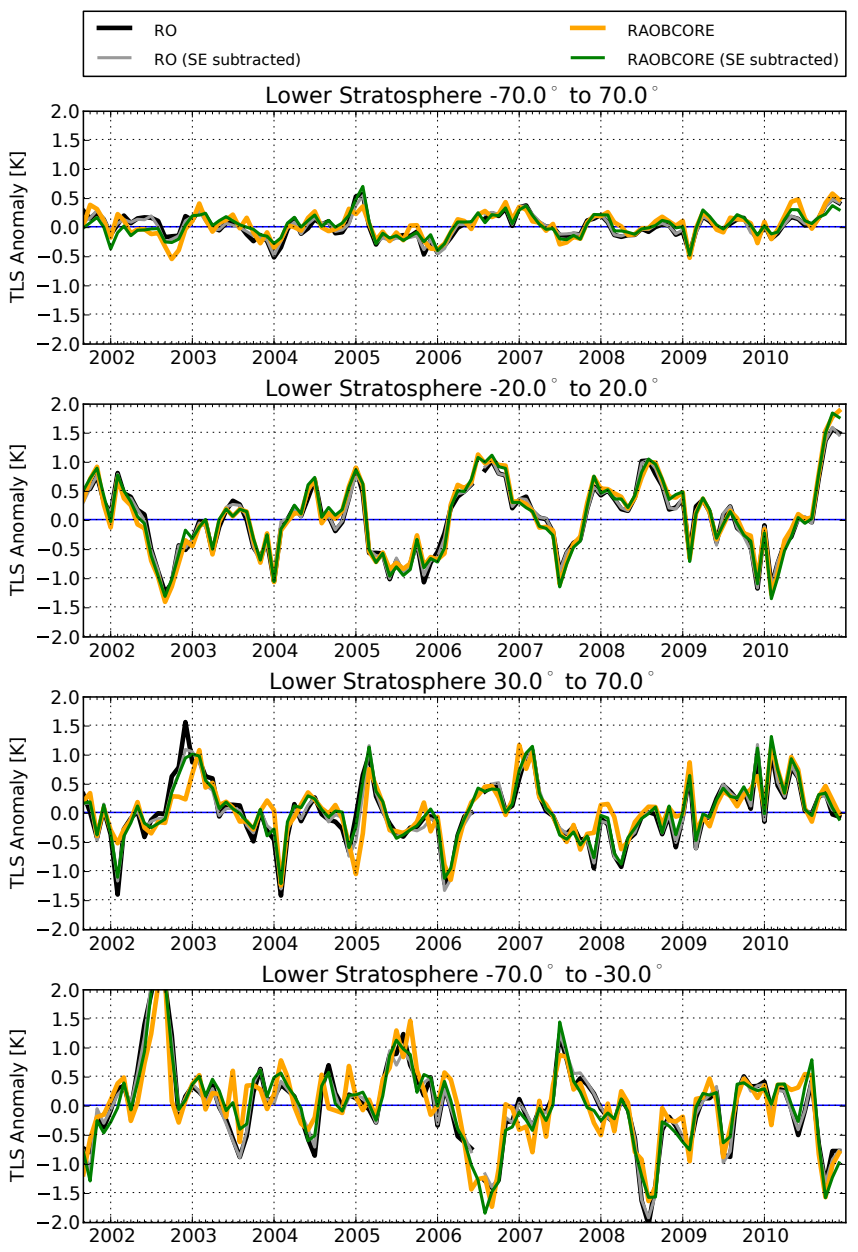

Fig. 6. TLS anomalies before/after subtracting the sampling error for RO (black/grey) and for RAOBCORE (orange/green). Shown for quasi-global region, tropics, and for $\mathrm{NH} / \mathrm{SH}$ extratropics (top to bottom).

Temporal sampling of radiosondes (00:00 UTC and 12:00 UTC) seems to basically capture the diurnal variation up to the semi-diurnal cycle. This was investigated by using only 00:00 UTC and 12:00 UTC time layers of the reference field for calculating the sampling error, instead of the "full" field of four time layers. Comparing the sampling error based on 00:00 UTC and 12:00 UTC time layers with that based on the "full" field showed very small differences only.

The effect of subtracting the respective sampling error from RO and radiosonde anomalies is shown in Fig. 6 for the large-scale zonal bands defined above. It is especially pronounced in $\mathrm{NH}$ and $\mathrm{SH}$ extratropics. The distinct influence of the sampling error correction in $\mathrm{NH}$ winter is clearly visible, as well as the all-year random effect in the SH extratropics. Generally, the radiosonde data get significantly closer to the RO time series after removing the sampling error. In the following, the $\mathrm{RO}$ and radiosonde datasets are 


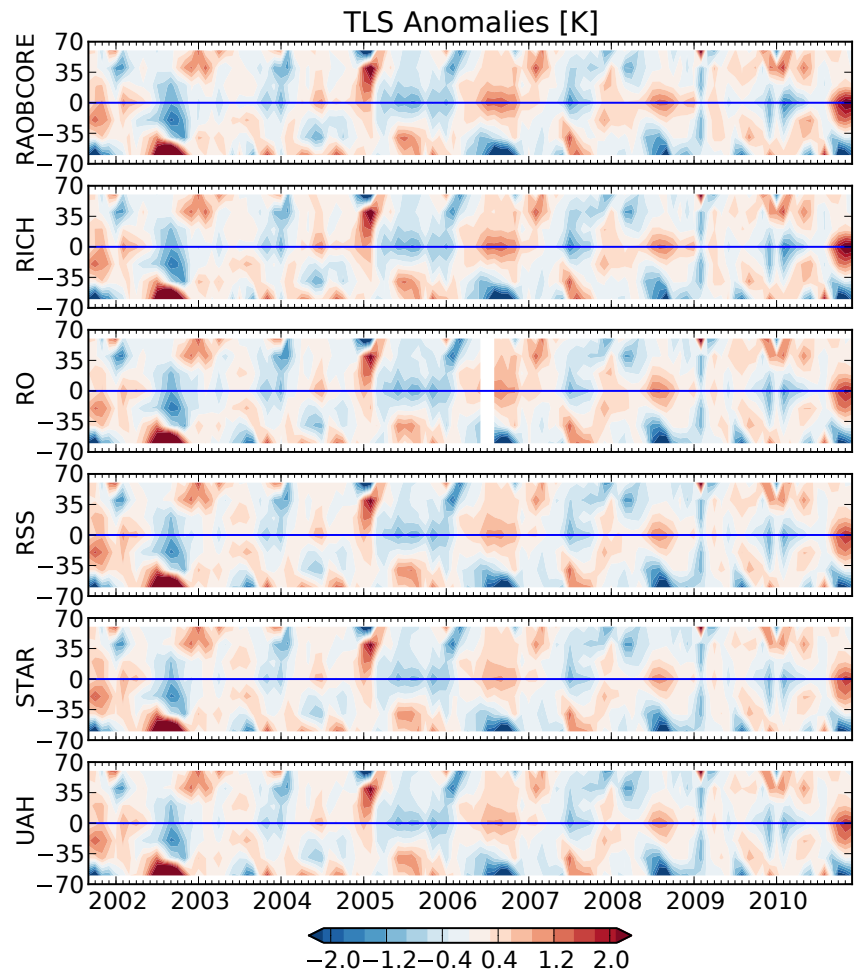

Fig. 7. Evolution of TLS anomalies for radiosondes (RAOBCORE, RICH), RO, and (A)MSU (RSS, STAR, UAH) (top to bottom), shown at $20^{\circ}$ resolution.

always being used in the corrected form of having their respective sampling errors subtracted. We focus on $70^{\circ} \mathrm{S}$ to $70^{\circ} \mathrm{N}$ to avoid sampling problems at polar latitudes.

\subsection{TLS anomalies and anomaly differences}

The TLS anomalies of all datasets are shown in Fig. 7 at $20^{\circ}$ latitudinal resolution for $70^{\circ} \mathrm{S}$ to $70^{\circ} \mathrm{N}$. Overall, the anomaly patterns of the various datasets are consistent. Figure 8 shows TLS anomaly time series for the investigated large-scale zonal bands. The anomalies show good agreement over the whole time range. The anomaly trend values are summarized in Table 1 . We observe statistically significant (at $95 \%$ significance level) negative TLS trends in the global mean for all (A)MSU datasets. These negative trends mostly stem from the SH extratropics, where the trend values are in rough agreement with Randel et al. (2009). In the tropics the trend values are positive for the TLS brightness temperature anomalies for all datasets, though statistically not significant (except for RO, showing low significance). This probably is a result from the coarse vertical resolution of TLS MSU-equivalents, where TLS derives from integrating over upper troposphere/lower stratosphere parts of the tropics (Randel et al., 2009). As shown by Schmidt et al. (2010), RO detects a positive trend signal in the tropics around the
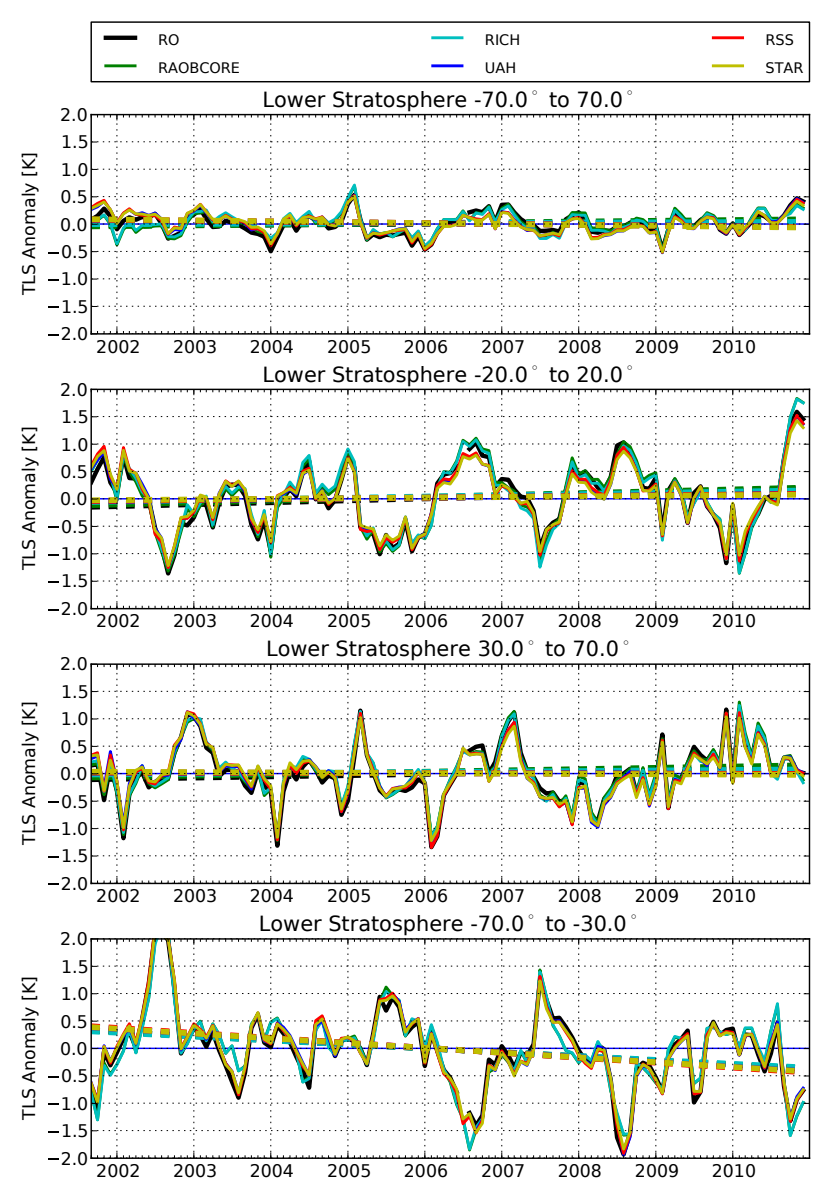

Fig. 8. TLS anomaly time series for all datasets, shown for quasiglobal, tropical, and NH/SH extratropical zonal bands (top to bottom). The linear regression lines are shown as dashed lines.

tropical tropopause, most probably strongly influencing the integral TLS. We do not further enter here into a climatological interpretation of the trends (which is difficult because of the short time period involved) but focus below on the structural differences of the datasets.

The differences of radiosonde and (A)MSU anomalies to RO anomalies are shown in Fig. 9 at $20^{\circ}$ latitudinal resolution and in Fig. 10 for the large-scale zonal regions. The anomaly difference trend values are summarized in Table 2. RAOBCORE and RICH show nearly negligible trends in their difference to $\mathrm{RO},(0.08 \pm 0.06) \mathrm{K} / 10 \mathrm{yr}$ and $(-0.01 \pm$ $0.07) \mathrm{K} / 10 \mathrm{yr}$ globally, which indicates that they do not diverge in time relative to RO. A moderate exception of this can be observed for the RICH dataset in the tropics and $\mathrm{NH}$, with difference trend values of $(-0.13 \pm 0.09) \mathrm{K} / 10 \mathrm{yr}$ and $(-0.13 \pm 0.06) \mathrm{K} / 10 \mathrm{yr}$. The above mentioned problem of the radiosonde network to correctly capture $\mathrm{NH}$ winter atmospheric variations is visible in the $\mathrm{NH}$ and quasi-global latitudinal bands. These differences are much more pronounced 


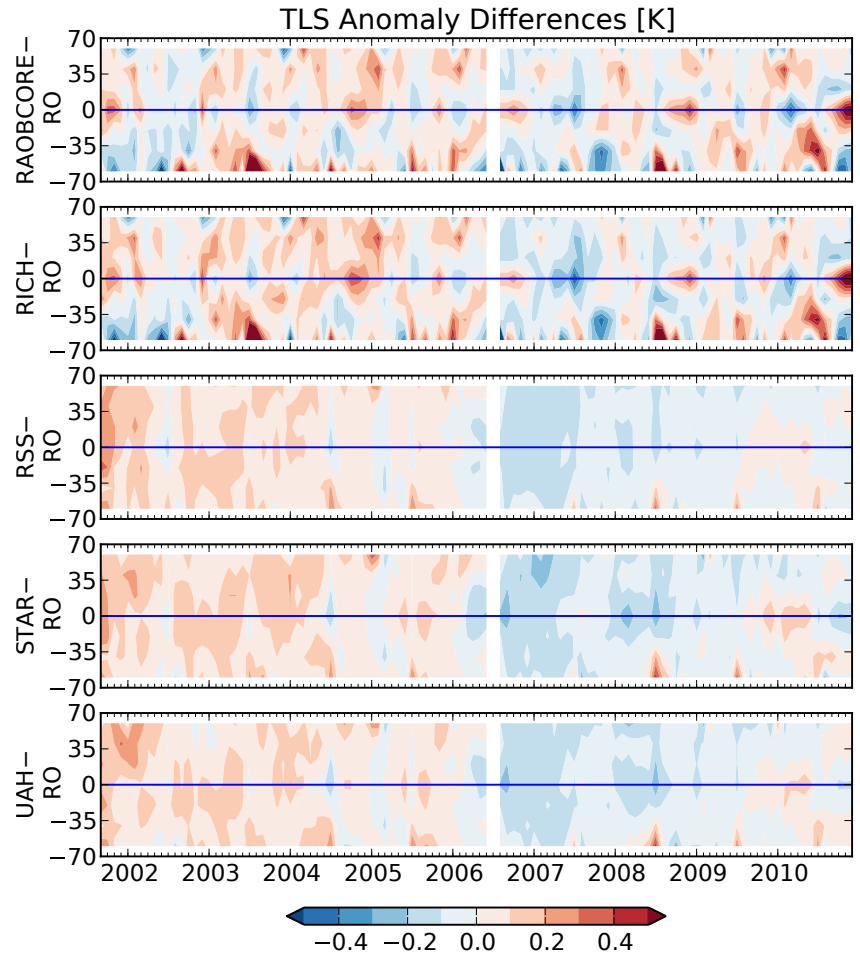

Fig. 9. Evolution of TLS anomaly differences of radiosonde (RAOBCORE, RICH) and (A)MSU (RSS, STAR, UAH) datasets to $\mathrm{RO}$ at $20^{\circ}$ resolution (top to bottom).

if the radiosonde datasets are not corrected for their sampling error (not shown; cf. Fig. 6).

The TLS anomaly difference trend of (A)MSU relative to $\mathrm{RO}$ is within about $(-0.2 \pm 0.1) \mathrm{K} / 10 \mathrm{yr}$ throughout all latitude ranges, and statistically significant everywhere and for all three (A)MSU datasets (with relatively smallest values of about $(-0.14 \pm 0.05) \mathrm{K} / 10 \mathrm{yr}$ in the $\mathrm{SH}$ and relatively largest ones of about $(-0.26 \pm 0.05) \mathrm{K} / 10 \mathrm{yr}$ in the $\mathrm{NH})$.

These results are visually summarized in Fig. 11, and also include the respective difference of the radiosonde datasets to a representative (A)MSU dataset (STAR) and the difference of RAOBCORE to RICH, all with their $95 \%$ confidence interval.

\section{Summary and conclusions}

This study focused on comparing (A)MSU data and radiosonde data to radio occultation data, which are well qualified as reference dataset for climate applications. We included RO data from CHAMP, SAC-C, GRACE-A, and F3C satellites for the time period September 2001 to December 2010. All RO profiles were transformed to MSU-equivalent layer-average brightness temperatures (TLS) using a radiative transfer model (RTTOV). Using inter-satellite consistency, the RO data were combined to form a single TLS

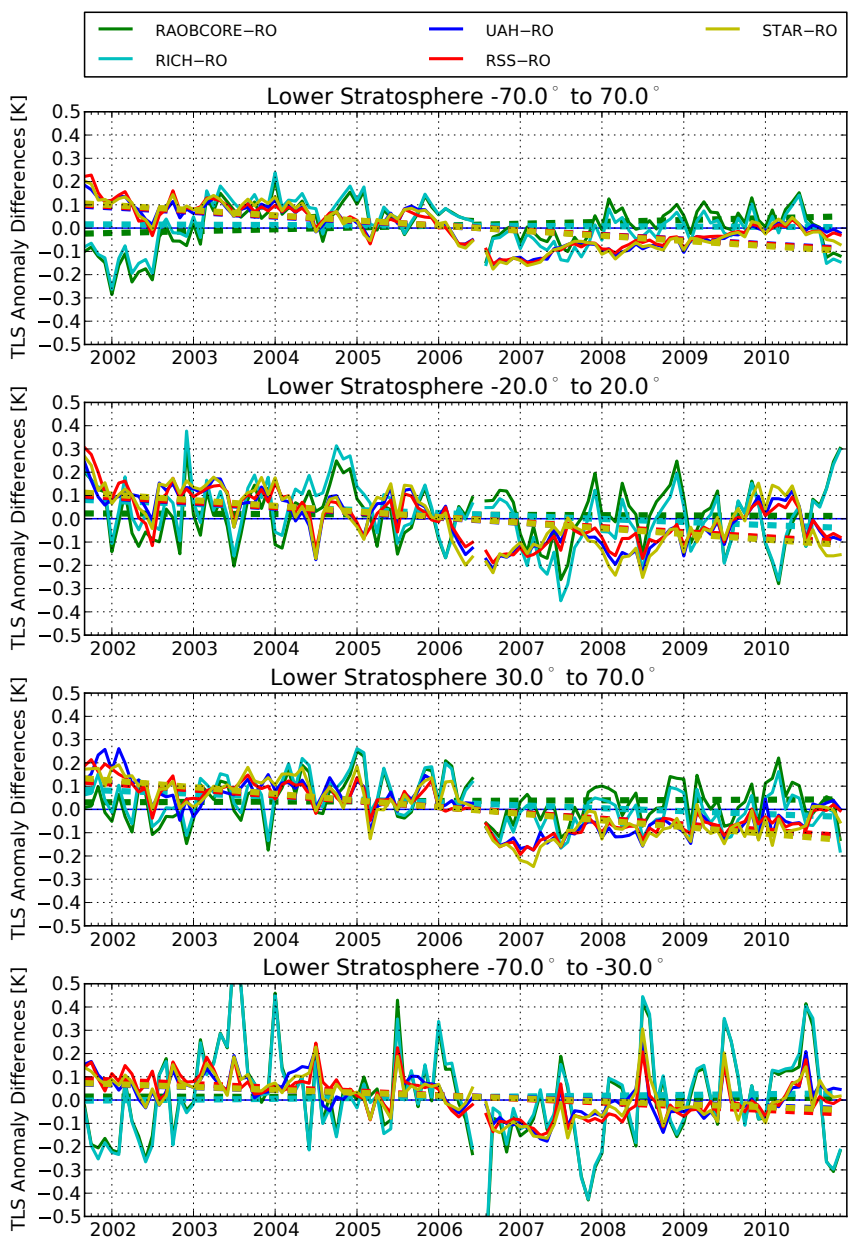

Fig. 10. TLS anomaly difference time series for all datasets, shown for quasi-global, tropical, and NH/SH extratropical zonal bands (top to bottom). The linear regression lines are shown as dashed lines.

RO dataset. This dataset was compared to (A)MSU datasets (UAH, RSS, STAR) and recent homogenized radiosonde datasets (RAOBCORE, RICH).

We estimated the spatiotemporal sampling error of radiosonde and RO data. Comparing the RO reference anomalies with radiosonde anomalies, we showed the importance of taking into account these error characteristics also for radiosondes. The consistency of radiosondes and RO was improved substantially by subtracting their respective sampling errors. We thus compared radiosonde and RO datasets in corrected form, i.e., with their sampling errors subtracted. The resulting anomaly time series for TLS showed good agreement of radiosonde data with $\mathrm{RO}$.

Rather surprisingly, we found that it is also important to take into account the sampling error for radiosondes in the Northern Hemisphere $(\mathrm{NH})$ extratropics where radiosonde station coverage is generally very good. We conclude that this results from the radiosonde network missing 

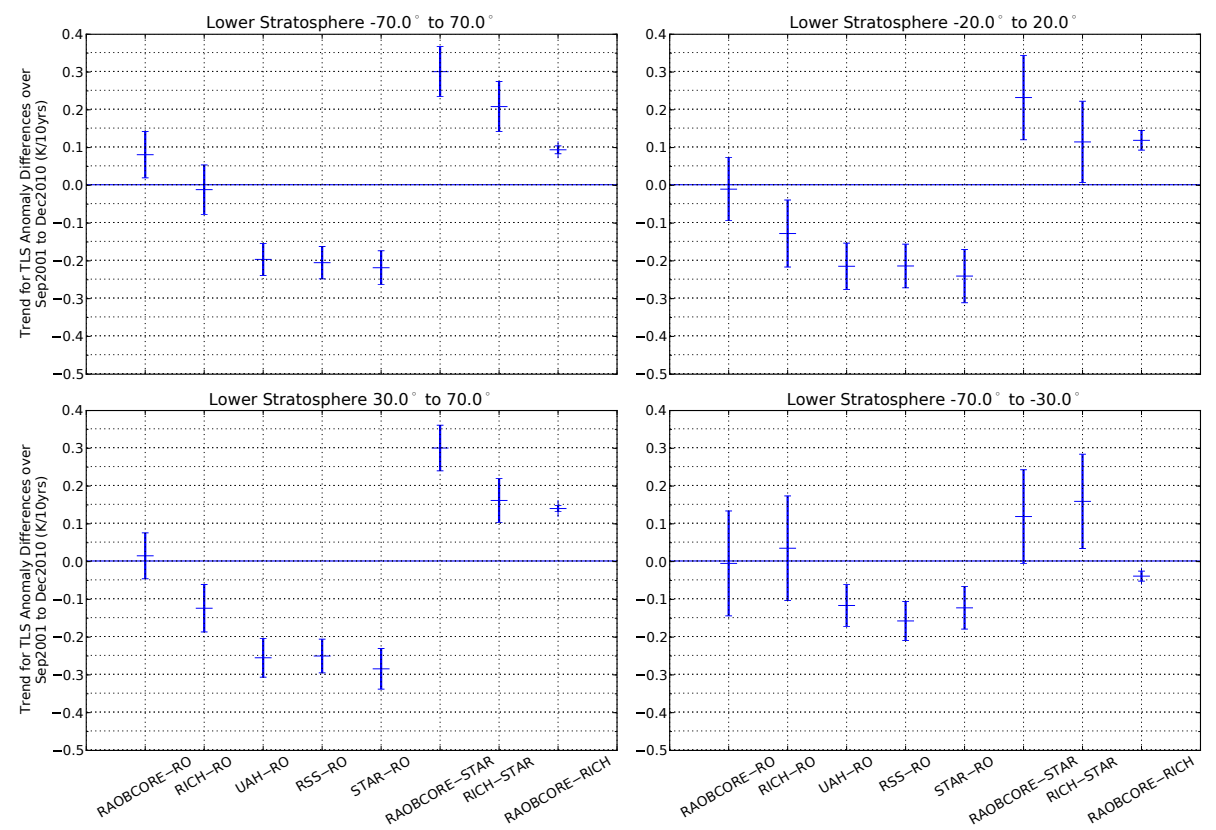

Fig. 11. Trend values of anomaly differences with $95 \%$ confidence interval for quasi-global, tropics, and NH/SH extratropics regions (top left to bottom right).

the atmospheric variability, particularly in $\mathrm{NH}$ winter. The advantage of homogeneously distributed measurements is thus clearly visible. In the tropics the deviations of radiosonde TLS from RO TLS are relatively small. This implies that despite the small number of stations in this region the sampling of radiosondes seems to be sufficient to largely capture the relatively homogeneous atmosphere in the tropics. RAOBCORE showed small to insignificant differences compared to RO in all of the three subregions. RICH also showed insignificant differences in the global mean. While RICH shows more cooling than RO in the tropics and NH, its anomalies still agree clearly better with RO than (A)MSU data. Generally radiosonde data showed larger errors in $\mathrm{SH}$ than elsewhere because the station coverage is very sparse there. Trends in TLS anomaly differences of radiosondes compared to RO were found to be small to insignificant in the global mean, $(0.08 \pm 0.06) \mathrm{K} / 10 \mathrm{yr}$ for RAOBCORE and $(-0.01 \pm 0.07) \mathrm{K} / 10 \mathrm{yr}$ for RICH.

(A)MSU data do not need sampling error correction because they provide very dense horizontal sampling. We found statistically significant trend values within about $(-0.2 \pm 0.1) \mathrm{K} / 10 \mathrm{yr}$ for the anomaly differences relative to $\mathrm{RO}$ in all large-scale zonal regions for all three (A)MSU datasets. This latitudinally consistent result somewhat deviates from the results of Steiner et al. (2007), who showed significant difference trends mainly in the tropics for the time period 2001 to 2006 . The difference trend values are smaller compared to Steiner et al. (2007), which we attribute to the longer time series, the most recent versions of RO and
(A)MSU data, and to a change in the difference trend characteristics of the (A)MSU record in 2006 where the negative trend tendency ceased to continue. The overall conclusion of Steiner et al. (2007) that multiple independent datasets are needed for detecting weaknesses in climate records remains valid.

The good vertical resolution of the $\mathrm{RO}$ and radiosonde data (compared to the layer-average TLS of the (A)MSU instrument) will be of advantage to further analyze and understand the differences. We expect the remaining differences to be easiest to explain in the tropics (which we will analyze in a future study). The high quality of RO measurements and the good agreement of radiosonde and RO anomalies indicate that the detected differences mainly stem from the (A)MSU data.

Acknowledgements. We are grateful to UCAR/CDAAC (USA) and WEGC (A) GPS RO operational team members for provision of RO data, at WEGC especially to J. Fritzer and B. Scherllin-Pirscher for their contributions to OPS system development and operations. We thank B. C. Lackner for fruitful discussions. UAH, RSS and NESDIS/STAR (all USA) are acknowledged for providing (A)MSU records. Furthermore we thank ECMWF (UK) for access to their atmospheric analysis data. This work was funded by the Austrian Science Fund (FWF; BENCHCLIM project P22293-N21, TRENDEVAL project P21642-N21, C. Tavolato and L. Haimberger supported by project P21772-N10). WEGC OPS development was co-funded by ESA/ESTEC Noordwijk, ESA/ESRIN Frascati, and FFG/ALR Austria. 
Edited by: K. B. Lauritsen

\section{References}

Anthes, R. A., Ector, D., Hunt, D. C., Kuo, Y.-H., Rocken, C., Schreiner, W. S., Sokolovskiy, S. V., Syndergaard, S., Wee, T.K., Zeng, Z., Bernhardt, P. A., Dymond, K. F., Chen, Y., Liu, H., Manning, K., Randel, W. J., Trenberth, K. E., Cucurull, L., Healy, S. B., Ho, S.-P., McCormick, C., Meehan, T. K., Thompson, D. C., and Yen, N. L.: The COSMIC/FORMOSAT3 mission: Early results, B. Am. Meteorol. Soc., 89, 313-333, doi:10.1175/BAMS-89-3-313, 2008.

Baldwin, M. P., Dameris, M., and Shepherd, T. G.: How will the stratosphere affect climate change?, Science, 316, 1576-1577, doi:10.1126/science.1144303, 2007.

Beyerle, G., Schmidt, T., Michalak, G., Heise, S., Wickert, J., and Reigber, C.: GPS radio occultation with GRACE: Atmospheric profiling utilizing the zero difference technique, Geophys. Res. Lett., 32, L13806, doi:10.1029/2005GL023109, 2005.

Christy, J. R., Spencer, R. W., and Lobl, E. S.: Analysis of the merging procedure for the MSU daily temperature time series, J. Climate, 11, 2016-2041, doi:10.1175/1520-0442-11.8.2016, 1998.

Christy, J. R., Spencer, R. W., Norris, W. B., Braswell, W. D., and Parker, D. E.: Error estimates of version 5.0 of MSU-AMSU bulk atmospheric temperatures, J. Atmos. Ocean. Tech., 20, 613629, doi:10.1175/1520-0426(2003)20;613:EEOVOM $i 2.0 . C O ; 2$, 2003.

Christy, J. R., Norris, W. B., Spencer, R. W., and Hnilo, J. J.: Tropospheric temperature change since 1979 from tropical radiosonde and satellite measurements, J. Geophys. Res., 112, D06102, doi:10.1029/2005JD006881, 2007.

Dee, D. P., Uppala, S. M., Simmons, A. J., Berrisford, P., Poli, P., Kobayashi, S., Andrae, U., Balmaseda, M. A., Balsamo, G., Bauer, P., Bechtold, P., Beljaars, A. C. M., van de Berg, L., Bidlot, J., Bormann, N., Delsol, C., Dragani, R., Fuentes, M., Geer, A. J., Haimberger, L., Healy, S. B., Hersbach, H., Hlm, E. V., Isaksen, L., Kllberg, P., Khler, M., Matricardi, M., McNally, A. P., Monge-Sanz, B. M., Morcrette, J.-J., Park, B.-K., Peubey, C., de Rosnay, P., Tavolato, C., Thpaut, J.-N., and Vitart, F.: The ERA-Interim reanalysis: configuration and performance of the data assimilation system, Q. J. Roy. Meteor. Soc., 137, 553-597, doi:10.1002/qj.828, 2011.

Foelsche, U., Borsche, M., Steiner, A., Gobiet, A., Pirscher, B., Kirchengast, G., Wickert, J., and Schmidt, T.: Observing upper troposphere-lower stratosphere climate with radio occultation data from the CHAMP satellite, Clim. Dynam., 31, 49-65, doi:10.1007/s00382-007-0337-7, 2008a.

Foelsche, U., Kirchengast, G., Steiner, A. K., Kornblueh, L., Manzini, E., and Bengtsson, L.: An observing system simulation experiment for climate monitoring with GNSS radio occultation data: setup and testbed study, J. Geophys. Res., 113, D11108, doi:10.1029/2007JD009231, 2008b.

Foelsche, U., Pirscher, B., Borsche, M., Kirchengast, G., and Wickert, J.: Assessing the climate monitoring utility of radio occultation data: From CHAMP to FORMOSAT-
3/COSMIC, Terr. Atmos. Ocean. Sci., 20, 155-170, doi:10.3319/TAO.2008.01.14.01(F3C), 2009.

Foelsche, U., Scherllin-Pirscher, B., Ladstädter, F., Steiner, A. K., and Kirchengast, G.: Refractivity and temperature climate records from multiple radio occultation satellites consistent within $0.05 \%$, Atmos. Meas. Tech. Discuss., 4, 1593-1615, doi:10.5194/amtd-4-1593-2011, 2011.

Free, M. and Seidel, D. J.: Causes of differing temperature trends in radiosonde upper air data sets, J. Geophys. Res., 110, D07101, doi:10.1029/2004JD005481, 2005.

GCOS: Implementation plan for the Global Observing System for Climate in support of the UNFCCC, (2010 Update), WMOTD/No. 1523 GCOS-138 (GOOS-184, GTOS-76), WMO, 2010.

Haimberger, L.: Homogenization of radiosonde temperature time series using innovation statistics, J. Climate, 20, 1377-1403, doi:10.1175/JCLI4050.1, 2007.

Haimberger, L., Tavolato, C., and Sperka, S.: Toward elimination of the warm bias in historic radiosonde temperature records-Some new results from a comprehensive intercomparison of upper-air data, J. Climate, 21, 4587-4606, doi:10.1175/2008JCLI1929.1, 2008.

Hajj, G. A., Kursinski, E. R., Romans, L. J., Bertiger, W. I., and Leroy, S. S.: A technical description of atmospheric sounding by GPS occultation, J. Atmos. Sol-Terr. Phy., 64, 451-469, doi:10.1016/S1364-6826(01)00114-6, 2002.

Hajj, G. A., Ao, C. O., Iijima, B. A., Kuang, D., Kursinski, E. R., Mannucci, A. J., Meehan, T. K., Romans, L. J., de la Torre Juarez, M., and Yunck, T. P.: CHAMP and SAC-C atmospheric occultation results and intercomparisons, J. Geophys. Res., 109, D06109, doi:10.1029/2003JD003909, 2004.

He, W., Ho, S.-p., Chen, H., Zhou, X., Hunt, D., and Kuo, Y.-H.: Assessment of radiosonde temperature measurements in the upper troposphere and lower stratosphere using COSMIC radio occultation data, Geophys. Res. Lett., 36, L17807, doi:10.1029/2009GL038712, 2009.

Ho, S.-P., Kuo, Y.-H., Zeng, Z., and Peterson, T.: A comparison of lower stratosphere temperature from microwave measurements with CHAMP GPS RO data, Geophys. Res. Lett., 34, L15701, doi:10.1029/2007GL030202, 2007.

Ho, S. P., Goldberg, M., Kuo, Y. H., Zou, C. Z., and Schreiner, W.: Calibration of temperature in the lower stratosphere from microwave measurements using COSMIC Radio Occultation data: preliminary results, Terr. Atmos. Ocean. Sci., 20, 87-100, doi:10.3319/TAO.2007.12.06.01(F3C), 2009a.

Ho, S.-P., Kirchengast, G., Leroy, S., Wickert, J., Mannucci, T., Steiner, A., Hunt, D., Schreiner, W., Sokolovskiy, S., Ao, C., Borsche, M., von Engeln, A., Foelsche, U., Heise, S., Iijima, B., Kuo, Y.-H., Kursinski, E., Lackner, B., Pirscher, B., Ringer, M., Rocken, C., , and Schmidt, T.: Estimating the uncertainty of using GPS radio occultation data for climate monitoring: Intercomparison of CHAMP refractivity climate records from 2002 to 2006 from different data centers, J. Geophys. Res., 114, D23107, doi:10.1029/2009JD011969, 2009b.

Karl, T. R., Hassol, S. J., Miller, C. D., and Murray, W. L. (eds.): Temperature trends in the lower atmosphere: Steps for understanding and reconciling differences, U.S. Climate Change Science Program/Subcommittee on Global Change Research, 2006

Kuo, Y.-H., Schreiner, W. S., Wang, J., Rossiter, D. L., and Zhang, Y.: Comparison of GPS radio occultation 
soundings with radiosondes, Geophys. Res. Lett., 32, L05817, doi:10.1029/2004GL021443, 2005.

Kursinski, E. R., Hajj, G. A., Schofield, J. T., Linfield, R. P., and Hardy, K. R.: Observing Earth's atmosphere with radio occultation measurements using the Global Positioning System, J. Geophys. Res., 102, 23429-23465, 1997.

Leroy, S., Dykema, J., and Anderson, J.: Climate Benchmarking Using GNSS Occultation, in: Atmosphere and Climate: Studies by Occultation Methods, edited by Foelsche, U., Kirchengast, G., and Steiner, A., 287-301, doi:10.1007/3-540-34121-8_24, Springer Berlin Heidelberg, 2006.

Mears, C. A. and Wentz, F. J.: Construction of the RSS V3.2 lowertropospheric temperature dataset from the MSU and AMSU microwave sounders, J. Atmos. Ocean. Tech., 26, 1493-1509, doi:10.1175/2009JTECHA1237.1, 2009a.

Mears, C. A. and Wentz, F. J.: Construction of the remote sensing systems V3.2 atmospheric temperature records from the MSU and AMSU microwave sounders, J. Atmos. Ocean. Tech., 26, 1040-1056, doi:10.1175/2008JTECHA1176.1, 2009b.

Melbourne, W. G., Davis, E. S., Duncan, C. B., Hajj, G. A., Hardy, K. R., Kursinski, E. R., Meehan, T. K., Young, L. E., and Yunck, T. P.: The application of spaceborne GPS to atmospheric limb sounding and global change monitoring, JPL Publication, 94-18, 147, 1994.

Pirscher, B., Foelsche, U., Lackner, B., and Kirchengast, G.: Local time influence in single-satellite radio occultation climatologies from Sun-synchronous and non-Sun-synchronous satellites, J. Geophys. Res., 112, D11119, doi:10.1029/2006JD007934, 2007.

Pirscher, B.: Multi-satellite climatologies of fundamental atmospheric variables from radio occultation and their validation (Ph.D. thesis), Sci. Rep. No. 33, Wegener Center Verlag Graz, Austria, 2010.

Randall, R. M. and Herman, B. M.: Using limited time period trends as a means to determine attribution of discrepancies in microwave sounding unit-derived tropospheric temperature time series, J. Geophys. Res., 113, D05105+, doi:10.1029/2007JD008864, 2008.

Randel, W. J., Shine, K. P., Austin, J., Barnett, J., Claud, C., Gillett, N. P., Keckhut, P., Langematz, U., Lin, R., Long, C., Mears, C., Miller, A., Nash, J., Seidel, D. J., Thompson, D. W. J., Wu, F., and Yoden, S.: An update of observed stratospheric temperature trends, J. Geophys. Res., 114, D02107, doi:10.1029/2008JD010421, 2009.

Saunders, R.: RTTOV-9 Science and Validation Report, NWP SAF NWPSAF-MO-TV-020, EUMETSAT, 2008.

Scherllin-Pirscher, B., Kirchengast, G., Steiner, A. K., Kuo, Y.H., and Foelsche, U.: Quantifying uncertainty in climatological fields from GPS radio occultation: an empirical-analytical error model, Atmos. Meas. Tech. Discuss., 4, 2749-2788, doi:10.5194/amtd-4-2749-2011, 2011.

Scherllin-Pirscher, B., Steiner, A., Kirchengast, G., Kuo, Y.-H., and Foelsche, U.: Empirical analysis and modeling of errors of atmospheric profiles from GPS radio occultation, Atmos. Meas. Tech. Discuss., 4, 2599-2633, doi:10.5194/amtd-4-2599-2011, $2011 \mathrm{~b}$.

Schmidt, T., Wickert, J., and Haser, A.: Variability of the upper troposphere and lower stratosphere observed with GPS radio occultation bending angles and temperatures, J. Adv. Space Res., 46, 150-161, doi:10.1016/j.asr.2010.01.021, 2010.

Schrøder, T., Leroy, S., Stendel, M., and Kaas, E.: Val- idating the microwave sounding unit stratospheric record using GPS occultation, Geophys. Res. Lett., 30, 1734, doi:10.1029/2003GL017588, 2003.

Seidel, D. J., Angell, J. K., Christy, J., Free, M., Klein, S. A., Lanzante, J. R., Mears, C., Parker, D., Schabel, M., Spencer, R., Sterin, A., Thorne, P., and Wentz, F.: Uncertainty in signals of large-scale climate variations in radiosonde and satellite upper-air temperature datasets, J. Climate, 17, 2225-2240, doi:10.1175/15200442(2004)017;2225:UISOLC ¿2.0.CO;2, 2004.

Solomon, S., Qin, D., Manning, M., Chen, Z., Marquis, M., Averyt, K., Tignor, M., and Miller, H., eds.: IPCC, 2007: Climate Change 2007: The Physical Science Basis. Contribution of Working Group I to the Fourth Assessment Report of the Intergovernmental Panel on Climate Change, Cambridge University Press, Cambridge, United Kingdom and New York, NY, USA, 2007.

Steiner, A., Kirchengast, K., Foelsche, U., Kornblueh, L., Manzini, E., and Bengtsson, L.: GNSS occultation sounding for climate monitoring, Phys. Chem. Earth, 26, 113-124, doi:10.1016/S1464-1895(01)00034-5, 2001.

Steiner, A., Kirchengast, G., Borsche, M., Foelsche, U., and Schoengassner, T.: A multi-year comparison of lower stratospheric temperatures from CHAMP radio occultation data with MSU/AMSU records, J. Geophys. Res., 112, D22110, doi:10.1029/2006JD008283, 2007.

Steiner, A., Kirchengast, G., Borsche, M., and Foelsche, U.: Lower stratospheric temperatures from CHAMP RO compared to MSU/AMSU records: An analysis of error sources, in: New Horizons in Occultation Research: Studies in Atmosphere and Climate, edited by: Steiner, A., Pirscher, B., Foelsche, U., and Kirchengast, G., Springer, Berlin Heidelberg, doi:10.1007/9783-642-00321-9_18, 2009a.

Steiner, A., Kirchengast, G., Lackner, B., Pirscher, B., Borsche, M., and Foelsche, U.: Atmospheric temperature change detection with GPS radio occultation 1995 to 2008, Geophys. Res. Lett., 36, L18702, doi:10.1029/2009GL039777, 2009b.

Sun, B., Reale, A., Seidel, D. J., and Hunt, D. C.: Comparing radiosonde and COSMIC atmospheric profile data to quantify differences among radiosonde types and the effects of imperfect collocation on comparison statistics, J. Geophys. Res., 115, D23104, doi:10.1029/2010JD014457, 2010.

Thompson, D. W. J. and Solomon, S.: Recent stratospheric climate trends as evidenced in radiosonde data: Global structure and tropospheric linkages, J. Climate, 18, 4785-4795, doi:10.1175/JCLI3585.1, 2005.

Thorne, P. W., Parker, D. E., Christy, J. R., and Mears, C. A.: Uncertainties in climate trends: Lessons from upper-air temperature records, B. Am. Meteorol. Soc., 86, 1437-1442, doi:10.1175/BAMS-86-10-1437, 2005.

Titchner, H. A., Thorne, P. W., McCarthy, M. P., Tett, S. F. B., Haimberger, L., and Parker, D. E.: Critically reassessing tropospheric temperature trends from radiosondes using realistic validation experiments, J. Climate, 22, 465-485, doi:10.1175/2008JCLI2419.1, 2009.

Wickert, J., Reigber, C., Beyerle, G., König, R., Marquardt, C., Schmidt, T., Grunwaldt, L., Galas, R., Meehan, T. K., Melbourne, W. G., and Hocke, K.: Atmosphere sounding by GPS radio occultation: First results from CHAMP, Geophys. Res. Lett., 
28, 3263-3266, doi:10.1029/2001GL013117, 2001.

Zou, C.-Z. and Wang, W.: Stability of the MSU-derived atmospheric temperature trend, J. Atmos. Ocean. Tech., 27, 19601971, doi:10.1175/2009JTECHA1333.1, 2010.
Zou, C.-Z., Gao, M., and Goldberg, M. D.: Error structure and atmospheric temperature trends in observations from the Microwave Sounding Unit, J. Climate, 22, 1661-1681, doi:10.1175/2008JCLI2233.1, 2009. 